\title{
Factors associated with problematic internet use among children and adolescents with Attention Deficit Hyperactivity Disorder
}

\author{
(1) Fatma Hulya Cakmak, ${ }^{1}$ (1) Hesna Gul ${ }^{2}$ \\ ${ }^{1}$ Department of Child and Adolescent Psychiatry, Dr. Sami Ulus Children Hospital, Ankara, Turkey \\ ${ }^{2}$ Department of Child and Adolescent Psychiatry, Gulhane Research and Training Hospital, Ankara, Turkey
}

\begin{abstract}
OBJECTIVE: The aim of this study was to determine the association of problematic internet use with attention deficit hyperactivity disorder (ADHD), personal risk factors, and familial factors and compare with a healthy control group and investigate the risk factors.

METHODS: The study sample consisted of 34 children aged 12-16 years and their families who applied to Ankara University Faculty of Medicine Department of Child and Adolescent Psychiatry with the diagnosis of ADHD. The control group consisted of 36 junior high and high school children aged 12-16 years and their families. The control group was matched with the ADHD group for age and sex. The Kiddie Schedule for Affective Disorders and Schizophrenia Present and LifetimeVersion (K-SADS$\mathrm{PL}$ ) version was used according to the Diagnostic and Statistical Manual of Mental Disorders (DSM)-IV criteria for patients with ADHD and the control group. Internet/Computer Use Assessment Questionnaire for Children/Adolescents, the Strengths and Difficulties Questionnaire adolescent form (SDQ), and Online Cognition Scale (OCS) were applied to children. Internet/ Computer Use Assessment Questionnaire for Parents and SDQ-parent form and Family Assessment (FAS) were applied to the parents.
\end{abstract}

RESULTS: Weekly internet usage was higher in the ADHD group than the control group. The OCS total scores and subscale scores were significantly higher in the ADHD group. The subscales of SDQ hyperactivity, conduct problems, and peer problems were significantly higher in the ADHD group. FAS-general functions, communication, roles and behavior control subscale scores were higher in the ADHD group. There was no significant difference between groups regarding the internet usage in the daily life, with the availability of a computer and internet at home. In the ADHD group, there was a significant correlation between the OCS scores, weekly internet usage, and psychiatric comorbidities Oppositional Defiant Disorder and Conduct Disorder. Also, affective responsiveness subscale scores of FAS were significantly correlated with OCS scores in the ADHD group.

CONCLUSION: In this study, it was noted that problematic internet use was more frequent in ADHD. During ADHD treatment, problematic internet use may interfere in the treatment goals. Interventions to problematic internet use should consider familial emotional expression studies.

Keywords: Attention Deficit Hyperactivity Disorder; child; family; risk factors; problematic internet use.

Cite this article as: Cakmak FH, Gul H. Factors associated with problematic internet use among children and adolescents with Attention Deficit Hyperactivity Disorder. North Clin Istanb 2018;5(4):302-313. 
T he use of computers and the internet has become an indispensable tool of life in the era of technology. Internet is a communication and data sharing platform that enables individuals to access all information easily and communicate quickly with other individuals irrespective of the distance between them $[1,2]$.

There are a number of risks of the internet even though it saves time, shortens distances, and makes life easier. The internet is regarded as a technological miracle supporting the individual development of children and adolescents, including their access to information, research, problem solving, creativity, and critical thinking $[3,4]$. However, the internet has been stated to negatively affect the development of personal skills owing to the excessive, uncontrolled, and non-purposeful use $[5,6]$.

Although the problematic use of the internet can be seen at any age, adolescents are reported to be one of the major risk groups [7]. It has been stated that because of the adolescents' proximity and attraction to technology, they use the internet more frequently than the other age groups. Adolescents' continuing cognitive, emotional, and social developments are more prone to the problematic use of the internet in their developmental period [8-11]. Brown et al. pointed out that young people tend to use the internet as a form of socialization, and children and adolescents are more likely to exchange real life activities with the virtual reality and emotion [12].

In a study performed in adults, it has been reported that excessive internet use was associated with unemployment, marital problems, neglect of children, and sleep disorders [13]. Internet addiction in South Korea began to be regarded as a public health problem [10] after 10 cardiopulmonary deaths [14] and a murder [15] related to a game occurred [16]. Moreover, it has been reported that there is an inverse relationship between time spent with internet games and academic achievement, and a significant relationship between aggression and violent games [17].

According to literature reviews, one of the important conditions associated with problematic use of the internet, especially in the adult group, is Attention Deficit Hyperactivity Disorder (ADHD) [18-25]. Children and adolescents with internet addiction were reported to be 2.51 times more likely to have ADHD than their non-addicted peers $[18,21,25]$. Studies in adolescents and young adults have shown that there is no significant difference between age groups in relation to ADHD-internet addiction or dependency in these groups and that internet addiction is significantly more common in the male gender $[18,21,22,26-28]$. In addition, many studies have determined that the scores of attention deficit and mobility, which are among the basic ADHD symptoms scores, were higher $[20,25,29-32]$ in the internet addiction group.

The issue has also attracted interest in Turkey in recent years. Population-based studies have been conducted in university and high school students [8, 33-37]. However, a limited number of studies have been performed in the smaller age groups in which ADHD was clinically diagnosed and supported by a detailed psychiatric examination.

The purpose of this study was to investigate the relationship between personal risk factors, familial factors, $\mathrm{ADHD}$, and the problematic use of the internet, which is increasingly seen in clinical practice in our country among children and early adolescents and compare them with a healthy control group to investigate the factors (if any).

The hypotheses of this study were determined as follows:

- Problematic internet use is more frequent in children and adolescents diagnosed with ADHD than in normal controls.

- The presence of additional diagnoses, such as Oppositional Defiant Disorder (ODD) and Depression and Conduct Disorder, increases the frequency and severity of problematic internet use.

- Broken familial rapport increases the frequency and severity of problematic internet use.

\section{MATERIALS AND METHODS}

\section{Sampling}

Following the approval of the study reviewed by the ethics committee of the University of Ankara Faculty of Medicine, 34 children aged 12-16 years who were referred to and followed up with the diagnosis of ADHD by Polyclinic of Child and Adolescent Mental Health and Diseases of Psychiatry Department of Ankara University Faculty of Medicine between April 2013 and June 2013 and their families constituted the ADHD group, and 36 age-matched children selected among sixth, seventh, and eighth grade students of a primary school ninth and tenth grade students of a lycée and their families were included in the study as a control group.

Individuals who were clinically thought to have mental 
retardation and those with medical conditions, including epilepsy, asthma, or physical disability, were not included in the study. Participants and their families were given detailed information about the survey and written consent was obtained indicating that they voluntarily agreed to participate in the survey.

\section{Data collection tools}

\section{Sociodemographic Data Form:}

In this form prepared by the researcher, the sociodemographic characteristics of the child/adolescent and parents were questioned (parental age, education level and occupation, monthly income, family structure, number of siblings, and children).

Internet/Computer Usage Assessment Questionnaire

(Parent and Child form) for children and adolescents:

It was prepared specifically for the research and included the following:

+ From where is the child connected to the internet?

- What is the intention of top priority for using the internet?

+ For how long is the internet used (hour/week)?

+ What time of the day internet is used?

+ Which types of sites are preferred?

+ How many years are computer/internet being used?

+ School success?

+ Are there rules for internet use at home?

Two separate forms have been prepared for parents and children.

Strengths and Difficulties Questionnaire Forms (for parents, teachers, and adolescents):

The Strengths and Difficulties Questionnaire (SDQ) is a 25-item Likert-type questionnaire developed by Robert Goodman in 1997 for the purpose of questioning emotional and behavioral problems together with some favorable characteristics of children and adolescents aged 4-16 years [38]. Questions on the scale are answered by parents, teachers, and adolescents as "not correct", "partially correct," and "absolutely correct" and scored " 0 ", " 1 ," and " 2 ," respectively. Questions 7, 11, 14, 21, and 25 of the scale are scored by reversing.

It consists of five subscales related to emotional problems, conduct problems, and peer relationship problems. As the scores of hyperactivity subscales increase, predisposition to problematic clinical increases, and as the scores of social behavior subscales increase, predisposition to problematic clinical conditions decreases.

As each subtitle is evaluated within itself, the sum of the first four subscale scores gives the "total difficulty score." The total score obtained from the scale is between 0 and 40 points. A higher total score indicates increased frequency of problematic behaviors of the child or youth. The increase in social behavior subscale scores indicates that the child is less prone to clinical problems. Therefore, unlike the other subscale and total scores, increase in social behavior subscale score is a favorable indicator.

Forms of this questionnaire designed for 4-16-year old individuals were to be responded by parents and teachers, and forms to be responded by 11-16-year -old adolescents themselves can be completed within nearly 5 minutes. The adaptation of SDQ to Turkish language was realized by Guvenir et al. in 2008 [39].

\section{Online cognition scale}

Developed by Davis, the online cognition scale (OCS) consists of 36 items that question the thoughts, attitudes, and beliefs about the internet [40]. OCS is a 7 point Likert-type scale with scores ranging from "I absolutely disagree" ( 1 point) to "I strongly agree" ( 7 points). The Turkish validity-reliability study of the OCS scale was conducted in 2005. According to the result of our study, its reliability coefficient was $\alpha=0.93$, and the test- retest reliability was $r=0.87$ [41]. There are four dimensions of the OCS:

1. Loneliness-Depression (2-, 22-, 23-, 24-, 25-, and 35-point items): The dimension of loneliness-depression includes depressive thoughts about excessive/ problematic/inappropriate use of internet.

2. Diminished Impulse Control (4-, 5-, 10-, 11-, 12-, 15-, 17-, 21-, 34-, and 36-point items): Diminished impulse control related to the use of the internet, failed attempts to limit the use of the internet, and tendency to engage in risky and dangerous behaviors.

3. Social Support Subdimension (1-, 3-, 6-, 7-, 8-, 9-, 13-, 14-, 16-, 18-, 19-, 26-, and 31-point items): Relates to the assumption that internet use of individuals may be associated with hypersensitivity to seeking social support or social rejection.

4. Distraction (2-, 27-, 28-, 29-, 30-, 32-, and 33-point items): Subdimension that expresses the situation related to avoidance of anticipated duties in relation to the person's identity and responsibilities. It evaluates 
resorting to internet with the intention to postpone some tasks or jobs.

In addition, item 12 is scored by reversing. The assessment of the scale is done by calculating total score and subscale scores. Generally, the high scores of the OCS give an idea of the value attributed to internet and the priority of the internet in the individual's life.

\section{Family Assessment Scale}

Developed by Epstein and Bishop, Family Assessment Scale (FAS) is a measure of the extent to which the family can or cannot fulfill its functions on specific matters. It consists of 60 items.

Family members rate each item with scores ranging between 1 and 4 points according to representability of each item, and they are asked to mark the items that most appropriately define their condition. Its translation to Turkish and the validity and reliability study was performed by Iş1 Bulut. FAS consists of seven subscales. Seven subscales consist of problem solving, communication, roles, emotional responsiveness, paying required attention, behavioral control, and general functions [42].

Schedule for Affective Disorders and Schizophrenia for School Aged - Kiddie- Present and LifetimeVersion:

Schedule for Affective Disorders and Schizophrenia for School Aged Children Kiddie-SADS Present and LifetimeVersion (K-SADS-PL) is a semi-structured diagnostic interview developed with the aim to assess the present and future psychopathology of children and adolescents according to the Diagnostic and Statistical Manual of Mental Disorders (DSM-III) and DSM-IV diagnostic criteria.

It was adapted from K-SADS-P in 1997 by Kaufman et al. [43]. The validity and reliability study of its Turkish adaptation was realized in 2004 by Gokler et al. [44].

The current psychiatric diagnosis of the children who participated in the study was determined according to the DSM-IV [45] diagnostic criteria using the MDQ-SCI.

\section{Statistical evaluation}

Statistical analyses were performed using the Statistical Package for Social Sciences, version 18.0, statistical package program. The Kolmogorov-Smirnov normality test was used for the analysis of fitness of the data to the normal distribution before starting the analyses. The Chi-square test and/or Fisher's exact test were used
TABLE 1. Sociodemographic Characteristics

\begin{tabular}{lccc} 
& ADHD & Control & $\mathrm{p}$ \\
\hline $\begin{array}{c}\text { Gender } \\
\text { Female }\end{array}$ & $11(32.4 \%)$ & $13(36.1 \%)$ & 0,741 \\
Male & $23(67.6 \%)$ & $23(63.9 \%)$ & \\
Age, years & $13.50 \pm 1.41$ & $13.50 \pm 1.42$ & 0.932 \\
Education & & & \\
Mother & $9.7 \pm 3.6$ & $5.7 \pm 1.6$ & $<0.001$ \\
Father & $10.1 \pm 3.7$ & $7.8 \pm 2.3$ & 0.001 \\
\hline
\end{tabular}

ADHD: Attention deficit hyperactivity disorder.

to compare categorical variables. The Student t-test was used to compare continuous variables, and the MannWhitney $U$ test was used when normal distribution was not obtained. Pearson and Spearman correlation analysis methods were used to determine the correlation among continuous data. In all statistical evaluations, the level of statistical significance was accepted as $\mathrm{p}<0.05$.

\section{RESULTS}

A total of 70 children and adolescents, including 34 ADHD (11 females and 23 males) and 36 healthy controls (13 females and 23 males), participated in the study. The mean age of the group of ADHD and control group was $13.50 \pm 1.4$ years. There were no significant differences between groups in terms of age and gender. It was observed that the level of education of the parents of the children with ADHD was significantly higher than that of the control group, indicating a significant difference between the parents of the ADHD and control groups (Table 1).

When the level of familiarity with internet and the intentions of its use in the groups were examined, it was observed that the ADHD group used computer for longer periods $(p=0.008)$ and the weekly duration of internet use was significantly higher than that of the control group ( $p=0.009)$. When the purposes of internet use were compared, the ADHD group engaged more frequently in social sharing sites, e-mail, betting sites, online games, chatting sites, dating sites, shopping sites, web design, and media access such as TV and music videos. This difference was statistically significant in terms of usage of e-mail, online games, and chat sites. In contrast, the con- 
TABLE2. Comparison of the levels of familiarity of children, and adolescents with Internet, and computer use

\begin{tabular}{|c|c|c|c|c|c|}
\hline & $\mathrm{n}$ & $\%$ & $\mathrm{n}$ & $\%$ & $\mathrm{p}$ \\
\hline Internet use & 33 & 97.1 & 33 & 91.7 & $0.615^{1}$ \\
\hline Having computer at home & 33 & 97.1 & 31 & 86.1 & 0.1991 \\
\hline Uninterrupted internet access at home & 28 & 82.4 & 25 & 69.4 & $0.208^{2}$ \\
\hline Weekly internet use (hours) (mean \pm SD) & \multicolumn{2}{|c|}{$15.73 \pm 14.36$} & \multicolumn{2}{|c|}{$7.66 \pm 6.90$} & $0.009^{3}$ \\
\hline \multicolumn{6}{|l|}{ Purposes of using Internet } \\
\hline Social networking site & 25 & 73.5 & 21 & 58.3 & 0.181 \\
\hline E-mailing & 14 & 41.2 & 6 & 16.7 & $0.023^{1}$ \\
\hline Search for information & 21 & 61.8 & 30 & 83.3 & $0.043^{1}$ \\
\hline Chatting & 17 & 50 & 5 & 13.9 & $0.001^{1}$ \\
\hline Dating sites & 1 & 2.9 & 0 & 0 & 0.486 \\
\hline Shopping sites & 4 & 11.8 & 1 & 2.8 & 0.192 \\
\hline Web design, blogs & 3 & 8.8 & 1 & 2.8 & 0.350 \\
\hline Pornographic sites & 0 & 0 & 0 & 0 & \\
\hline News portals & 6 & 17.6 & 9 & 25 & 0.454 \\
\hline Media (TV, music, video etc) & 21 & 61.8 & 17 & 47.2 & 0.222 \\
\hline Betting sites & 3 & 8.8 & 2 & 5.6 & 0.669 \\
\hline Other & 2 & 5.9 & 0 & 0 & 0.232 \\
\hline
\end{tabular}

ADHD: Attention deficit hyperactivity disorder; SD: Standard deviation; ${ }^{1}$ Fisher's exact test; ${ }^{2}$ Pearson chi-square test, ${ }^{3}$ Mann-Whitney U test.

trol group was found to be more frequently interested in searching information, using homework sites, loading offline games, and reading newspapers and news, and this difference was statistically significant in the fields of accessing information and homework sites (Table 2).

When the scale scores of the groups were examined, it was found that in the subscale scores of "Communication," "Roles," "Behavior Control," and "General Family Functions" of the FAS appeared to be statistically significantly higher in the ADHD group (Table 3).

Parents of children in the ADHD group assigned significantly higher scores to all the subscale items of OCS compared with the control group (Table 3).

Parents of children in the ADHD group assigned significantly higher scores to subscale items of "Strengths and Difficulties Questionnaire Problems," including Conduct Problems, Hyperactivity, Peer Relationship Problems, and Prosocial Behaviors, than the parents of the control group (Table 3).

The rates of additional diagnoses in the ADHD group were investigated using K-SADS. Spearman correlation analyses showed a mild-to-moderate positive correlation between OCS scores and ODD and Conduct Disorders in the ADHD group. It was also determined that as the education level of the mother increased, the total scores of the OCS also increased, which indicated the presence of a weak correlation between these parameters (Table 4).

The relationship between the total score of OCS and other subscale scores was examined using the Pearson correlation analysis. As the scores related to the problematic internet use increased, scores of dysfunction related to the emotional reactions in the family increased, and the adolescents using the internet had more frequently indicated emotional and conduct problems related to themselves. 
TABLE 3. Comparison of various scale scores of the groups

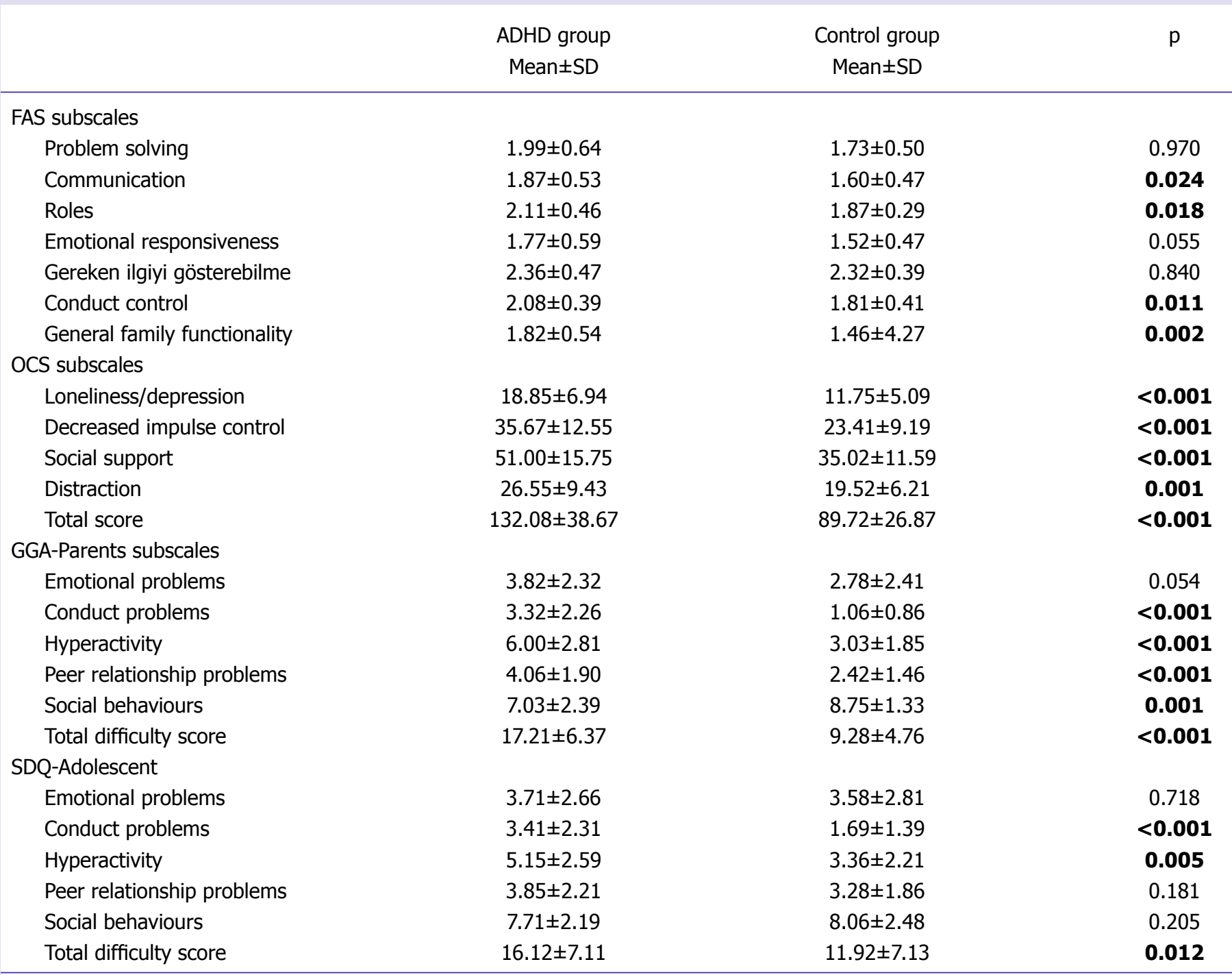

SD: Standard deviation; OCS: Online Cognition Scale; SDQ: Strengths and Difficulties Questionnaire; FAS: Family Assessment Scale; ADHD: Attention deficit hyperactivity disorder; Mann-Whitney $U$ test.

Problems related to problem solving, communication, and roles in family functionality were positively correlated with adolescent self-report and behavioral scores and negatively and moderately with SDQ-parents-social behavior scores. This situation was interpreted as the problems of the puberty increased when the problemsolving skill in the family decreased. In addition, negative relationships with the subscale of SDQ-parents-social behaviors, which reveal the social skills of adolescents, indicate that these problems in the family can lead to problems in social relations (Table 5).

\section{DISCUSSION}

In our study, the factors related to problematic internet use by children and adolescents were investigated. Problematic internet use has been found to be more frequent in children and adolescents with ADHD. When the patterns of internet use among children and adolescents with ADHD were examined, it was found that the presence of accompanied ODD and Conduct Disorders (CD), longer periods of internet use, and disordered family functionality related to emotional reactions was associated with problematic internet use. 
TABLE 4. Relationship between the presence of additional diagnosis,educational levels of the parents, and OCD scores in the ADHD group

\begin{tabular}{lcc} 
& \multicolumn{2}{c}{ OCD (total score) } \\
\cline { 2 - 3 } & $\mathrm{r}$ & $\mathrm{p}$ \\
\hline Presence of an additional diagnosis & $\mathbf{0 . 4 5 1}$ & $\mathbf{0 . 0 0 7}$ \\
Depression & 0.170 & 0.337 \\
Separation anxiety & 0.096 & 0.591 \\
Phobia & 0.134 & 0.450 \\
OCD & -0.028 & 0.875 \\
ODD & 0.343 & 0.047 \\
Conduct disorder & 0.358 & 0.038 \\
SLD & -0.182 & 0.303 \\
Educational level & & \\
$\quad$ Mother & .237 & 0.024 \\
\multicolumn{1}{c}{ Father } & -.074 & 0.271 \\
\hline
\end{tabular}

Spearman Correlation Analysis; ADHD: Attention deficit hyperactivity disorder; OCD: Obsessive compulsive disorder; ODD: Oppositional defiant disorder; SLD: Specific learning difficulty; OCS: Online cognition scale.

When patient groups were examined in terms of additional psychiatric disorders, $70.6 \%$ of the patients in the ADHD group had additional psychiatric diagnoses at a significantly higher rate relative to the control group. It has been suggested that $60-100 \%$ of ADHD patients have one or more additional psychiatric diagnoses [46]. The most common comorbidities in ADHD in order of their decreasing frequency are Oppositional Defiant Disorder (ODD), learning disorders, CD, anxiety disorders, and depression $[47,48]$. In our study, ODD (26.5\%), depression (23.5\%), and CD (17.6\%) were most frequently diagnosed in the ADHD group.

When the levels of children and adolescents' acquaintance with computer and internet were examined, no difference between both groups was noted in terms of the factors, such as using internet in daily life, having a computer, and internet access at home. These results are important in that they demonstrate that internet and the computer occupy an important part in the lives of children and young people, independent of the economic conditions of the family. In contrast, although the opportunities of internet access were reported as comparable, it has been determined that the ADHD group used computers and internet for statistically significantly longer periods compared to the control group, suggesting that access to computers, internet, and technology products is easier and more frequent in recent years. However, it also reveals that ADHD children and their parents who are genetically predisposed to ADHD have been at increased risk for the problematic internet use.

When the time spent by children and adolescents using the computer and internet was examined, it was found that the ADHD group spent significantly longer periods, with an average of $15.73 \pm 14.36$ hours per week. Problematic internet use was reported as over 8.48 hours per week in a study performed by MorahanMartin and Schumaher [49]. In the study by Kelleci et al. performed in our country, it has been reported that the daily use of internet of over 2 hours is related to mental disorders [34].

In a study performed by Uneri et al. in high school students, it was stated that the increase in the time spent on the internet is related to internet dependency [36]. In a population-based study, Yolga-Tahiroglu et al. defined the use of internet for 12 hours or more per week as problematic internet use [35]. We found that children and adolescents with ADHD who participated in this study had clinically significant internet dependency with longer use per week compared with the control group

When the children and adolescents were examined in terms of the places where internet and computer were used, the control group had more frequently used computers at school, while no statistically significant difference was detected in terms of other locations of computer use. In our study, the respective percentages of children and adolescents in the ADHD group stated that they preferred to use computer and internet at home (85.3\%), internet café (17.6\%), and school (8.8\%).

The children and adolescents in the control group stated that they preferred to use internet and computer at home $(74.3 \%)$, internet café $(17.1 \%)$, and school (31.4\%). In a similar study conducted with male university students in our country, the respective percentages of students stated that they were using computer and internet at home $(80.6 \%)$, school $(8.7 \%)$, and internet café $(9.2 \%)$ [50]. It is thought that the increased use of computer and internet at home among adolescents between the ages of 12 and 24 years has contributed to the higher frequency of internet use at home.

When the children and adolescents were examined according to their purpose of using internet and computer, the patients in the ADHD group used internet more frequently for e-mailing, playing online games, and chatting. The control group used the internet more frequently than 
the ADHD group for searching information and doing homework. Social networking sites were used extensively by both groups, without any significant difference between them. Our results are also important in terms of demonstrating that online social media and gaming addiction, which are considered as new fads in recent years, carry a greater risk for adolescents with ADHD [25, 51-53].

Upon analysis, the mean OCS subscale and total scores rated by children and adolescents of the ADHD group were found to be significantly higher than those of the control group. Higher OCS scores give an idea about the value attributed to internet and the degree of its priority in the life of the individual. Based on this finding, it can be said that the ADHD group is more prone to use the internet problematically.

In another study, OCS scores of age-matched children and adolescents with ADHD were reported to be significantly higher than the population in general [54].

The average weekly internet usage hours and OCS scores of children and adolescents with ADHD who participated in the study were significantly higher than those of the control group; however, extreme values were observed when the distribution intervals were examined. What are the differences between children and adolescents with and without problematic internet and computer in the ADHD group? What are the factors that lead to these differences? To investigate the answers to these questions, the ADHD group has been examined within itself in terms of internet usage patterns. In our study, it was determined that as the duration of internet and computer use of children and adolescents in the ADHD

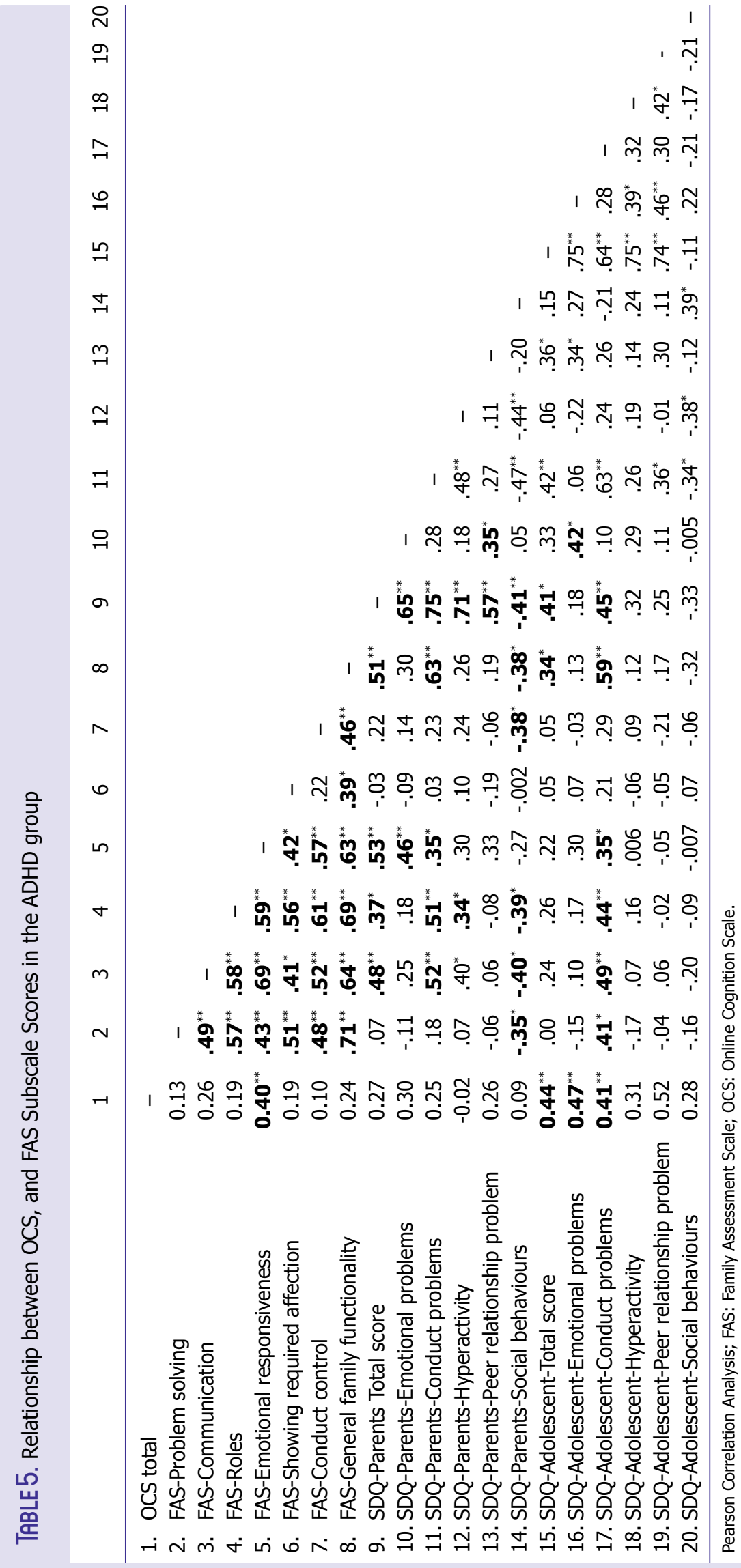


group increased, OCS scores increased. In contrast, as the time spent on the computer and internet increases, the rate of problematic usage, personal importance attributed to the internet by the user, and its priority in the life of the person also increase. In a study conducted in university students, a significant relationship was found between the OCS scores and the duration of weekly internet use [50]. Our study also supports this finding. When the relationship between OCS scores and weekly internet usage was examined in the ADHD group, a statistical but moderately significant correlation was found between the duration of weekly internet use and loneliness/depression, decreased impulse control, social support subscales, and their total scores. The strongest relationship was between the loneliness/ depression subscale scores and the duration of internet use. In a recent review that evaluated 20 studies, depression (75\%), anxiety (57\%), obsessive-compulsive symptoms (60\%), aggression (66\%), and ADHD $(100 \%)$ were detected in respective percentages of individuals with problematic internet use. In the light of the relevant literature, as was the case with other age groups, feelings of depression and loneliness were determined as important risk factors for the problematic internet use among adolescents with ADHD.

When the familiarity levels of the cases in the ADHD group with internet and computer are examined in relation with internet usage patterns, a significant correlation between the factors, such as using internet in daily life, having a computer and internet access at home, OCS scores, and weekly internet use was not detected. Although the duration of computer use (year) of the ADHD group was higher than that of the control group, no correlation was found between the OCS scores and duration of weekly internet use.

In a similar study performed with lyceé students, it has been reported that the presence of internet at home and youngster possessing a computer in his/her private room is not related to internet addiction [36]. In a study conducted with university students, no significant correlation was not found between the duration of internet use by the students in years, OCS scores, and duration of weekly internet use. Unlike our study, in this study, it was stated that young people with their own computers had higher OCS scores and weekly internet usage times [50].

When the relationship between the intention of using internet and computer and internet use patterns are examined in the ADHD group, online games were found to be moderately related to the OCS scores, while chatting was also moderately correlated with the duration of weekly use.

In a population-based study, Kormas et al, reported that using the internet for interactive gaming, chatting, and searching for sexual information is a predictor of problematic internet use [55]. In the study by Mottram et al. performed in adults aged older than 17 years, using internet for gaming and non-business purposes and being affiliated with online groups predicted problematic internet use [56]. In his study with adult internet addicts, Bernardi et al. stated that the use of internet for chatting in women and its use for interactive gaming in men is related to internet dependency [57].

When the relationship between comorbid psychiatric disorders and internet use patterns in the ADHD group was examined, the additional diagnoses of ODD and $C D$ were found to be significantly related to both the OCS scores and the duration of the weekly internet use.

According to literature reviews, although the association between ADHD and other mental disorders had been mentioned, it was noticed that there were no studies related to the additional diagnoses of CD and ODD accompanying ADHD. This is thought to be due to the use of different diagnostic tools, the use of self-reporting scale in most studies, and the lack of diagnostic evidence of conduct problems within them, as a result of the differences in the study methods and assessment methods.

In a recent study conducted in our country with clinical samples selected from adolescents and children aged 10-8 years who were diagnosed with internet addiction, ADHD was the most frequently diagnosed condition in $83.3 \%$ of the patients. In addition, incidence rates of ODD (23\%) and CD (15\%) were also consistent to the rates in our study, but it was not specified whether these diagnoses accompanied ADHD [58].

When the relationship between SDQ subscale scores and internet usage patterns was examined in the ADHD group, a moderately significant correlation between OCS scores and emotional and conduct problems and total difficulty subscale scores was detected. Only a moderately significant correlation was found between the duration of weekly use and the subscales of conduct problems in both SDQ-parent and SDQ-teacher forms. In the study by Kormas et al. where SDQ was used, the presence of a correlation between the conduct problems, hyperactivity subscale scores, and problematic internet use was indicated [55]. 
When the relationship between FAS subscale scores and internet use patterns was examined in the ADHD group, a statistically significant relationship was detected between OCS scores and emotional responsiveness subscale scores only. A moderately positive correlation between the OCS and this subscale indicates that the use of problematic internet increases when the unhealthy expression of emotional reactions in the family increases. This finding suggests that an adolescent who does not express his/her emotional reactions appropriately or an adolescent who does not receive appropriate emotional responses from his/her parents uses the internet more inefficiently. This is an important finding. Problems with internet use are commonly encountered in children with ADHD, and interventions to address this need should also address intrafamilial expressions of emotion.

A statistically significant relationship was not found between the duration of weekly internet use and FAS subscale scores. It has been also observed that other difficulties in family functionality generally increase the parents' negative scores in the SDQ regarding their children, and in this case, the adolescents themselves also overestimate conduct problems and mobility symptoms.

This condition may be related to two important factors. Firstly, ADHD may be the cause of both maladjustment of family functionality and problematic use of the internet; secondly, a chaotic family structure of adolescents with ADHD may be an additional risk factor that increases the effect of ADHD on the problematic use of the internet. It seems further studies are required related to this issue.

Our study has certain limitations. Only limited number of children were included in the study, which is not sufficient to generalize the results. In addition, the study group included cases with ADHD who were admitted to our clinic. Studies in the social sample can give different results. Another limitation is that the selected control group is at a lower socioeconomic level than the ADHD group. However, since the use of the internet has become widespread nowadays, the difference between the two groups is not important in terms of access to internet and computer use.

\section{Conclusion}

Our study is one of the first studies that compared the control group with ADHD group in terms of problematic internet use by youngsters in the early adolescence.
It also evaluated family functionality and its relationship to internet usage patterns. We hope that this study will shed light on other studies and warrant further similar studies.

Acknowledgment: We thank Prof. Dr Kagan Gurkan for his contribution to the collection, analysis and evaluation processes of the study data.

Conflict of Interest: The authors declare no conflict of interest.

Financial Disclosure: The authors declared that this study has received no financial support.

Authorship Contributions: Concept - F.H.C., H.G.; Design - F.H.C., H.G.; Supervision - F.H.C., H.G.; Materials - F.H.C., H.G.; Data collection \&/or processing - F.H.C., H.G.; Analysis and/or interpretation - F.H.C., H.G.; Writing - F.H.C., H.G.; Critical review - F.H.C., H.G.

\section{REFERENCES}

1. Esen E, Siyez DM. An Investigation of Psycho-Social Variables in Predicting Internet Addiction Among Adolescents [Article in Turkish]. Türk Psikolojik Danışma ve Rehberlik Dergisi 2011;4:127-38.

2. Gönül AS. Pathological internet use (Internet dependency /abuse) [Article in Turkish]. Yeni Symposium 2000;40:105-10.

3. Berson IR, Berson MJ. Digital Literacy for Effective Citizenship. Social Education 2003;67:164-7.

4. Kubey R. How Media Education Promotes Critical Thinking, Democracy, Health, and Aesthetic Appreciation. In: Thinking Critically About Media: Schools and Families in Partnership. Alexandria: Cable in the Classroom; 2002, p. 1-6.

5. Colwell J, Kato M. Investigation of the relationship between social isolation, self-esteem, agression and computer game play in Japanese adolescents. Asian Social Pyschology 2003;6:149-58. [CrossRef]

6. Kerber CJ. Problem and pathological gambling among college athletes. Ann Clin Psychiatry 2005;17:243-7. [CrossRef]

7. Öztürk Ö, Odabaşıŏlu G, Eraslan D, Genç Y, Kalyoncu ÖA. Internet addiction: Clinical aspects and treatment strategies [Article in Turkish]. Bağımlılık Dergisi 2007;8:36-41.

8. Ceyhan AA. Predictors of problematic Internet use on Turkish university students. Cyberpsychol Behav 2008;11:363-6. [CrossRef]

9. Widyanto L, McMurran M. The psychometric properties of the internet addiction test. Cyberpsychol Behav 2004;7:443-50. [CrossRef]

10. Tsai CC, Lin SS. Analysis of attitudes toward computer networks and Internet addiction of Taiwanese adolescents. Cyberpsychol Behav 2001;4:373-6. [CrossRef]

11. Yang SC, Tung CJ. Comparison of Internet addicts and non-addicts in Taiwanese high school. Computers in Human Behavior 2007;23:7996. [CrossRef]

12. Brown JD. Emerging Adults in a Media-Saturated World. In: Arnett JJ, Tanner JL, editors. Emerging adults in America: Coming of age in the 21st Century. Washington DC: American Psychological Association; 2006. [CrossRef]

13. Young KS. Internet addiction: The emergence of a new clinical disorder. Cyberpsychol Behav 1998;1:237-44. [CrossRef]

14. Choi YH. Advancement of IT and seriousness of youth Internet addiction. 2007 International Symposium on the Counseling and Treatment of Youth Internet Addiction. Seul, South Korea: National Youth Com- 
mission; 2007.

15. Koh Y. Development and application of K-Scale as diagnostic scale for Korean Internet addiction. 2007 International Symposium on the Counseling and Treatment of Youth Internet Addiction. Seoul, South Korea: National Youth Commission; 2007.

16. Block JJ. Issues for DSM-V: internet addiction. Am J Psychiatry 2008;165:306-7. [CrossRef]

17. Anderson CA, Dill KE. Video games and aggressive thoughts, feelings, and behavior in the laboratory and in life. J Pers Soc Psychol 2000;78:772-90. [CrossRef]

18. Yoo HJ, Cho SC, Ha J, Yune SK, Kim SJ, Hwang J, et al. Attention deficit hyperactivity symptoms and internet addiction. Psychiatry Clin Neurosci 2004;58:487-94. [CrossRef]

19. Ha JH, Yoo HJ, Cho IH, Chin B, Shin D, Kim JH. Psychiatric comorbidity assessed in Korean children and adolescents who screen positive for Internet addiction. J Clin Psychiatry 2006;67:821-6. [CrossRef]

20. Yen JY, Ko CH, Yen CF, Wu HY, Yang MJ. The comorbid psychiatric symptoms of Internet addiction: attention deficit and hyperactivity disorder (ADHD), depression, social phobia, and hostility. J Adolesc Health 2007;41:93-8. [CrossRef]

21. Yen JY, Yen CF, Chen CS, Tang TC, Ko CH. The association between adult ADHD symptoms and internet addiction among college students: the gender difference. Cyberpsychol Behav 2009;12:187-91.

22. Ko CH, Yen JY, Chen CS, Chen CC, Yen CF. Psychiatric comorbidity of internet addiction in college students: an interview study. CNS Spectr 2008;13:147-53. [CrossRef]

23. Young J. Common comorbidities seen in adolescents with attention-deficit/hyperactivity disorder. Adolesc Med State Art Rev 2008;19:21628.

24. Cho SC, Kim JW, Kim BN, Lee JH, Kim EH. Biogenetic temperament and character profiles and attention deficit hyperactivity disorder symptoms in Korean adolescents with problematic Internet use. Cyberpsychol Behav 2008;11:735-7. [CrossRef]

25. Wang BQ, Yao NQ, Zhou X, Liu J, Lv ZT. The association between attention deficit/hyperactivity disorder and internet addiction: a systematic review and meta-analysis. BMC Psychiatry 2017;17:260.

26. Cheng SH, Lee CT, Chi MH, Sun ZJ, Chen PS, Chang YF, et al. Factors related to self-reported attention deficit among incoming university students. J Atten Disord 2016;20:754-62. [CrossRef]

27. Yen JY, Liu TL, Wang PW, Chen CS, Yen CF, Ko CH. Association between Internet gaming disorder and adult attention deficit and hyperactivity disorder and their correlates: Impulsivity and hostility. Addict Behav 2017;64:308-13. [CrossRef]

28. Metin O, Saracli O, Atasoy N, Senormanci O, Cakir-Kardes V, Acikgoz $\mathrm{HO}$, et al. Association of Internet Addiction in High School Students with ADHD and Tobacco/Alcohol use. Düşünen Adam 2015;28:20412. [CrossRef]

29. Chen YL, Chen SH, Gau SSF. ADHD and autistic traits, family function, parenting style, and social adjustment for Internet addiction among children and adolescents in Taiwan: a longitudinal study. Res Dev Disabil 2015;39:20-31. [CrossRef]

30. Hyun GJ, Han DH, Lee YS, Kang KD, Yoo SK, Chung US, et al. Risk factors associated with online game addiction: a hierarchical model. Comput Hum Behav 2015;48:706-13. [CrossRef]

31. Dalbudak E, Evren C. The relationship of Internet addiction severity with Attention Deficit Hyperactivity Disorder symptoms in Turkish University students; impact of personality traits, depression and anxiety. Compr Psychiatry 2014;55:497-503. [CrossRef]

32. Dalbudak E, Evren C, Aldemir S, Taymur I, Evren B, Topcu M. The impact of sensation seeking on the relationship between attention deficit/hyperactivity symptoms and severity of Internet addiction risk. Psychiatry Res 2015;228:156-61. [CrossRef]

33. Ozcan NK, Buzlu S. Internet use and its relation with the psychosocial situation for a sample of university students. Cyberpsychol Behav 2007;10:767-72. [CrossRef]

34. Kelleci M, Güler N, Sezer H, Gölbaşı Z. Relationships Gender and Psychiatric Symptoms with Duration of Internet Use among High School Students [Article in Turkish]. TAF Prev Med Bull 2009;8:22330.

35. Tahiroğlu AY, Çelik G, Uzel M, Özcan N, Avci A. Internet use among Turkish adolescents. Cyberpsychol Behav 2008;11:537-43. [CrossRef]

36. Üneri ÖŞ, Tanıdır C. Evaluation of internet addiction in a group of high school students: a cross-sectional study [Article in Turkish]. Düşünen Adam 2011;24:265-72. [CrossRef]

37. Yılmaz S, Hergüner S, Bilgiç A, Işık Ü. Internet addiction is related to attention deficit but not hyperactivity in a sample of high school students. Int J Psychiatry Clin Pract 2015;19:18-23. [CrossRef]

38. Goodman R. The Strengths and Difficulties Questionnaire: a research note. J Child Psychol Psychiatry 1997;38:581-6. [CrossRef]

39. Güvenir T, Özbek A, Baykara B, Arkar H, Şentürk B, İncekaş S. Psychometric properties of the Turkish version of the Strengths and Difficulties Questionnaire (SDQ) [Article in Turkish]. Çocuk ve Gençlik Ruh Sağlığ1 Dergisi 2008;15:65-74.

40. Davis RA, Flett GL, Besser A. Validation of a new scale for measuring problematic Internet use: Implications for pre-employment screening. Cyberpsychol Behav 2002;5:331-45. [CrossRef]

41. Özcan NK, Buzlu S. Problemli internet kullanımını belirlemede yardımcı bir araç: “internette bilişsel durum ölçeği” nin üniversite öğrencilerinde geçerlik ve güvenirliği. Bağımlılık Dergisi 2005;6:19-26.

42. Bulut I. Aile değerlendirme ölçeği el kitabı. Ankara: Özgüzeliş Matbaas1; 1990 .

43. Kaufman J, Birmaher B, Brent D, Rao U, Flynn C, Moreci P, et al. Schedule for Affective Disorders and Schizophrenia for SchoolAge Children-Present and Lifetime Version (K-SADS-PL): initial reliability and validity data. J Am Acad Child Adolesc Psychiatry 1997;36:980-8. [CrossRef]

44. Gökler B, Ünal F, Pehlivantürk B, Kültür EÇ, Akdemir D, Taner Y. Okul Çağı Çocukları İçin Duygulanım Bozuklukları ve Şizofreni Görüşme Çizelgesi-Şimdi ve Yaşam Boyu Şekli-Türkçe Uyarlamasının Geçerlik ve Güvenirliği. Çocuk ve Ergen Ruh Sağlığı Dergisi 2004;11:109-16.

45. American Psychiatric Association. Diagnostic and Statistical Manual of Mental Disorders (DSM-IV). 4th ed. Washington DC: APA; 1994.

46. Rommelse NN, Altink ME, Fliers EA, Martin NC, Buschgens CJ, Hartman CA, et al. Comorbid problems in ADHD: degree of association, shared endophenotypes, and formation of distinct subtypes. Implications for a future DSM. J Abnorm Child Psychol 2009;37:793804. [CrossRef]

47. Bauermeister JJ, Shrout PE, Ramírez R, Bravo M, Alegría M, MartínezTaboas A, et al. ADHD correlates, comorbidity, and impairment in community and treated samples of children and adolescents. J Abnorm Child Psychol 2007;35:883-98. [CrossRef]

48. Gillberg C, Gillberg IC, Rasmussen P, Kadesjö B, Söderström H, Rås$\operatorname{tam} \mathrm{M}$, et al. Co-existing disorders in ADHD - implications for diagnosis and intervention. Eur Child Adolesc Psychiatry 2004;13 Suppl 1:I80-92. [CrossRef]

49. Morahan-Martin J, Schumacher P. Incidence and Correlates of Pathological Internet Use Among College Students. Article in Computers in Human Behavior 2000;16:13-29. [CrossRef] 
50. Sakarya D. Ankara Üniversitesi'nde Lisans Programlarında Eğitim Almakta Olan Erkek Öğrencilerde İnternet Kullanım Örüntüleri Üzerine Epidemiyolojik Bir Çalışma [Yayınlanmamış Uzmanlık Tezi]. Ankara: Ankara Üniversitesi; 2010.

51. Ryan T, Chester A, Reece J, Xenos S. The uses and abuses of Facebook: A review of Facebook addiction. Journal of Behavioral Addictions 2014;3:133-48. [CrossRef]

52. Carli V, Durkee T, Wasserman D, Hadlaczky G, Despalins R, Kramarz $\mathrm{E}$, et al. The association between pathological internet use and comorbid psychopathology: a systematic review. Psychopathology 2013;46:1-13.

53. Ho RC, Zhang MW, Tsang TY, Toh AH, Pan F, Lu Y, et al. The association between internet addiction and psychiatric co-morbidity: a metaanalysis. BMC Psychiatry 2014;14:183. [CrossRef]

54. Tarihoğlu AY, Çelik GG, Fettahoğlu Ç, Yıldırım V, Toros F, Avcı A, et al. Problematic Internet Use in the Psychiatric Sample Com- pared Community Sample [Article in Turkish]. Nöropsikiyatri Așivi 2010;47:241-6.

55. Kormas G, Critselis E, Janikian M, Kafetzis D, Tsitsika A. Risk factors and psychosocial characteristics of potential problematic and problematic internet use among adolescents: a cross-sectional study. BMC Public Health 2011;11:595. [CrossRef]

56. Mottram AJ, Fleming MJ. Extraversion, impulsivity, and online group membership as predictors of problematic internet use. Cyberpsychol Behav 2009;12:319-21. [CrossRef]

57. Bernardi S, Pallanti S. Internet addiction: a descriptive clinical study focusing on comorbidities and dissociative symptoms. Compr Psychiatry 2009;50:510-6. [CrossRef]

58. Bozkurt H, Coskun M, Ayaydin H, Adak I, Zoroglu SS. Prevalence and patterns of psychiatric disorders in referred adolescents with Internet addiction. Psychiatry Clin Neurosci 2013;67:352-9. [CrossRef] 